\title{
A systematic review of the concept and clinical applications of Bone Marrow Aspirate Concentrate in Orthopaedics
}

\author{
Mohamed A. Imam ${ }^{1,2, *}$, Samer S.S. Mahmoud ${ }^{3}$, James Holton ${ }^{1,2}$, Dalia Abouelmaati ${ }^{5}$, \\ Yasser Elsherbini ${ }^{5,6}$, and Martyn Snow $^{2,4}$ \\ 1 Department of Trauma and Orthopaedics, Faculty of Medicine, Suez Canal University, 41111 Ismailia, Egypt \\ 2 The Royal Orthopaedic Hospital, B31 2AP Birmingham, UK \\ 3 Health Education North East of England, NE15 8NY Newcastle, UK \\ 4 Birmingham University, B15 2TT Birmingham, UK \\ 5 Research and Development, OxCell, OX3 8AT Oxford, UK \\ 6 Institute of Biomedical Engineering, University of Oxford, OX3 7DQ Oxford, UK
}

Received 27 August 2016, Accepted 8 January 2017, Published online 6 March 2017

\begin{abstract}
Introduction: Mesenchymal stem cells (MSC's) are believed to have multipotent plasticity with the capability to differentiate along multiple cell lineages such as cartilage, bone, tendon, muscle, and nerve. Such multipotency has the potential to play an important role in the repair and reconstruction of multiple tissues across a number of orthopaedic specialties. Bone marrow and fat are the most abundant and accessible source of MSC's with bone marrow aspirate the most commonly being reported to stimulate healing.

Methods: This review examines the current reported 20 Q2 clinical applications of bone marrow aspirate concentrate and its effectiveness.

Results: The published studies reported techniques of collection and preparation of BMAC in addition to its applications in a number of orthopaedic sub-specialities. Studies could be sub-categorised into: techniques of extraction, processing and microscopic examination of BMAC (31), reconstruction of osseous defects/non-union (20), treatment of avascular necrosis (9), repair of cartilage defects (8), treatment of sports injuries and tendon injury/repair (9), injection in regenerative therapy (4), treatment of spine conditions (4) including enhancing postoperative fusion and degenerative disc pathology and orthopaedic oncology (4). A few published studies combined the use of platelet-rich plasma (PRP) with BMAC (4) or compared them in different applications (5).

Conclusions: BMAC has been used in bone, cartilage and tendon injuries with encouraging results.
\end{abstract}

Key words: Bone Marrow Aspirate Concentrate, BMAC, Mesenchymal Stem Cells.

\section{Introduction}

Mesenchymal stem cells (MSCs) [1] are believed to have multipotent plasticity with the capability to differentiate along multiple cell lineages such as cartilage, bone, tendon, muscle and nerve [1-6]. Such multipotency has the potential to play an important role in the repair and reconstruction of multiple tissues across a number of orthopaedic specialties. Bone marrow and fat are the most abundant and accessible source of MSCs with bone marrow aspirate the most commonly being reported to stimulate healing $[7,8]$.

\section{Bone Marrow composition}

The cellular composition of bone marrow aspirate in normal subjects has been studied by Bain using light microscopy

\footnotetext{
*Corresponding author: mohamed.imam@aol.com
}

[9]. On analysing small volumes $(0.1-0.2 \mathrm{~mL})$ in 50 subjects it was found that neutrophils and erythroblasts were the dominant cell type. Neutrophils were lower in males (32.7\%) compared with females $(37.4 \%)$ but erythroblasts were greater in males (28.1\%) compared with females $(22.5 \%)$, which is likely to represent the differences in adult haemoglobin concentrations. The other constituents included lymphocytes $13.1 \%$, eosinophils $2.2 \%$, blast cells 1.4 (immature white cells), monocytes $1.3 \%$ and basophils $0.1 \%$. There was a wide variation in the megakaryocyte percentage (platelet precursors) and this is likely to represent the wide variation in normal ranges in the adult population. Yamamura et al. [10] assessed the cellular composition using laser photometry, with the mean subpopulation percentages being consistent with Yamamura et al. [10]. Kim et al. found similar percentages using a flow cytometry technique analysing $2 \mathrm{~mL}$ of bone marrow [11]. Although the mechanism of cellular analysis differs the percentage of each cell type is largely similar (Table 1) [12]. 
Table 1. Results of cytological analysis of bone marrow aspirate and bone marrow concentrate [12].

\begin{tabular}{lccccc}
\hline & Bone marrow aspirate* & Bone marrow concentrate* & Absolute change* & Relative change $^{\dagger}$ & $p$-Value \\
\hline Platelet count $\times 103 / \mu \mathrm{L}$ & 31.1 & 208.3 & 177 & 8.7 & 0.002 \\
White blood-cell count $\times 103 / \mu \mathrm{L}$ & 36.5 & 267 & 230 & 7.4 & 0.0007 \\
Red blood-cell count $\times 103 / \mu \mathrm{L})$ & 6774 & 3156 & 3617 & 0.5 & $<0.0001$ \\
\hline
\end{tabular}

* These values are presented as the mean and standard deviation. $N=10$.

$\dagger$ The relative change is presented as the mean with the $95 \%$ confidence interval.

\section{Bone Marrow harvest}

The body has numerous potential areas for bone marrow harvest. Hyer et al. compared the iliac crest, tibia and calcaneus as widely accessible areas and assessed the number of osteoblastic connective tissue progenitor cells [13]. The iliac crest yielded a higher mean concentration of osteoblastic progenitor cells compared to the tibia and calcaneus. Gender, smoking status and diabetes were not predictive of osteoblastic progenitor cell concentration. However, with increasing age there is a reduction in the fibroblast colony forming units (CFU-F) and hence stem cells, which may have implications on efficacy in the elderly population [13].

Bantinic et al. looked at the aspirate from the first $1 \mathrm{~mL}$ and subsequent aspirates from the iliac crest. In subsequent samples, the nucleated cell population and CFU level were 3 and $10 \times$ lower than the first $1 \mathrm{~mL}$ of aspirate [14]. This work has been supported by Muschler et al. highlighting that as the volume of aspirate from the iliac crest increases from 2 to $4 \mathrm{~mL}$ the number of MSCs decreases by $50 \%$ [15]. This is likely due to the proportion of blood in the subsequent samples diluting the concentration of progenitor cells and colony forming units/stem cells. Muschler et al. [15] and Hernigou et al. [16] have defined the sector rule for the aspiration of marrow from the iliac crest, which is based on safety zones. They studied the anatomy of the iliac bone and its adjacent structures vulnerable to injury by the trocar when it is introduced into the iliac crest. The authors used computed tomography to examine 48 iliac crests in 24 pelvises. They divided the iliac crest into six equal sectors from anterior to posterior direction. The authors studied 480 trocar entry points undertaken by six surgeons among 120 patients. They demonstrated that the sector system consistently envisaged safe and unsafe zones for placing the trocar in the iliac crest. They observed increased risk of breaches on obese patients and this risk is decreased in more experienced surgeons. Ninety-four breaches out of 480 entry points occurred with increased risks observed in the thinner sectors in the iliac crest. Additionally, there is increased risk of injuring the external iliac artery in the four most anterior sectors (1-4) especially in females. On the other hand, posterior sectors were associated with increased risk of sciatic nerve and gluteal vessel injury when the trocar was inserted more than $6 \mathrm{~cm}$ into the posterior iliac crest. They concluded that the sector rule is a reliable system to use for bone marrow aspiration (BMA) [16]. Hernigou et al. in a separate study also identified that the use of $10 \mathrm{~mL}$ syringes to aspirate bone marrow was superior to $50 \mathrm{~mL}$ syringes. In 30 patients the $10 \mathrm{~mL}$ syringe aspirations resulted in progenitor cell concentrations on average 300\% higher. This was believed to be secondary to a larger negative pressure generated in the $10 \mathrm{~mL}$ syringe which preferentiallyremoved bone marrow cells and reduced blood contamination [17].

\section{Bone Marrow concentration}

The main concern in using BMA to stimulate tissue repair/ regeneration is that only $0.001 \%$ of nucleated cells within BMA are MSCs [9, 18-20]. To address this issue, various protocols have been developed to concentrate the nucleated cell numbers to produce bone marrow aspirate concentrate (BMAC). It is hoped that it would then have the sufficient amount of MSCs needed to provide an effective environment of healing and regeneration [20, 21].

Different techniques have been proposed to concentrate bone marrow aspirate to form BMAC. These include the use of Ficoll density gradients in the laboratory setting and automated, closed centrifugation systems in the clinical setting. The exact mechanism of action of BMAC is currently not fully understood. Potentially the MSCs contained within BMAC will provide a direct cell source for repair of the host tissue. Alternatively or in addition, the nucleated cells may have a significant paracrine effect delivering various cytokines and growth factors to orchestrate and direct host repair [22-25].

This review examines the currently reported clinical applications of BMAC and its effectiveness.

\section{Methods \\ Eligibility}

We have included all published clinical literature investigating the development, techniques and applications of BMAC. Language, design and risk of bias did not deter the initial inclusion of any study. Our search was exclusively limited to studies involving human subjects.

\section{Search Strategy}

A PRISMA-compliant search was carried out as published in 2009 [26]. This included the online databases: PubMed, EMBASE, ClinicalTrials.gov and the Cochrane library from 1960 to the end of May 2015. The Medical Subject Heading (MeSH) terms used included: "Bone" AND "Marrow" AND "Aspirate" AND "Concentrate". 


\section{Critical Appraisal}

Eligible studies were independently appraised by two authors using the Critical Appraisal Skills Program checklist. For the purpose of narrative review, relevant studies were included irrespective of methodology or level of evidence.

\section{Results}

Eighty-nine of the 122 (58 PubMed and 64 EMBASE) results yielded by the preliminary search were included. Exclusions included seven duplicate records, four letters, 22 non-orthopaedics related studies (11 vascular surgery, 10 maxillo-facial and one oncology) and two records irrelevant to our search topic.

On searching www.ClinicalTrials.gov, we found that 28 trials were registered. All trials examined the use of stem cells in different orthopaedic applications (Table 2). The CASP appraisal confirmed a satisfactory standard of all 89 studies [27].

The published studies reported techniques of collection and preparation of BMAC in addition to its applications in a number of orthopaedic sub-specialities. Studies could be subcategorised into: techniques of extraction, processing and microscopic examination of BMAC (31), reconstruction of osseous defects/non-union (20), treatment of avascular necrosis (9), repair of cartilage defects (8), treatment of sports injuries and tendon injury/repair (9), injection in regenerative therapy (4), treatment of spine conditions (4) including enhancing postoperative fusion and degenerative disc pathology and orthopaedic oncology (4). A few published studies combined the use of platelet-rich plasma (PRP) with BMAC (4) or compared them in different applications (5).

\section{Literature review}

Hernigou et al. highlighted that the efficacy of BMAC is dependent on the amount of progenitor cells in the concentrate. They compared the quantity and concentration of these cells in both BMA and BMAC aspirated from the iliac crest when used for the treatment of atrophic non-union of the tibia. The BMA contained a mean of $612 \pm 134$ compared to $2579 \pm 1121$ cells per $\mathrm{cm}^{3}$ in the BMAC group. Reduced concentration of progenitor cells at the non-union sites was significantly associated $(p<0.01)$ with non-union [28].

Different techniques have been proposed to concentrate the marrow aspirate to form BMAC. These include the use of Ficoll density gradients in the laboratory setting and automated, closed centrifugation systems in the clinical setting. Although these techniques increase the number of MSCs, they do not significantly increase the ratio of stem cells to other nucleated cells $[20,21,29]$. Centrifugation is the present technique of choice for the various commercially available products used in the clinical setting, although as shown in relation to PRP there is significant variation in the final end products achieved. Fortier et al. compared the constituents of PRP and BMAC, there are reduced platelets and raised white blood cells (WBCs) in BMAC demonstrating that this is a very different substance to PRP with a likely different mechanism of action [12].

\section{Bone defects}

Existing common approaches to managing bone defects involve using allograft bone or harvesting bone from a donor site, usually iliac crest. BMAC has been used to augment this approach with the aim of improving the incorporation of bone graft and in some cases replace it. BMAC utilisation in managing bone defects has been popularised as MSCs can differentiate into osteoblasts and are able to promote osteogenic differentiation in vitro without any osteogenic stimuli $[21-23,28,30]$.

Bone Marrow Aspirate Concentrate was used in the treatment of atrophic non-union in 60 patients by Hernigou et al. [28]. They reported a positive association between the quantity of hard callus and the number $(p=0.04)$ and concentration $(p=0.01)$ of fibroblast colony-forming (FCF) units in the graft. In the seven non-united tibias, the concentration $(p=0.001)$ and the total number $(p<0.01)$ of progenitors cells injected were significantly lower than in those that united. They also reported the time interval needed to achieve union was negatively correlated with the FCF units' concentration at the site of the graft $(p=0.04)$.

Lee et al. [22] demonstrated superior bone healing in a randomised trial using BMAC with PRP injections during distraction osteogenesis of the tibia in 20 patients (40 tibias). They compared patients receiving an osteotomy site injection of BMAC and PRP (treatment group) versus no injection (control group). The mean cortical healing indexes were significantly higher in the treatment group $(p<0.001)$. Although callus profile and type were not different between the two groups, full weight bearing was allowed earlier in the treatment group than in the control group (index: 0.99 months $/ \mathrm{cm}$ and 1.38 months $/ \mathrm{cm}$, respectively, $p<0.001)$. The main limitation with this study is that they did not evaluate whether the combination of BMAC or PRP has synergistic effects on bone regeneration. This query was addressed by Kassem [31] and Hernigou et al. [32], who revealed that the injection of BMAC alone is efficient in the management of non-union.

The use of BMAC with bone defects has clear potential for use in non-union and distraction osteogenesis. However, further trials are required to refine indications and establish a standardised methodology of preparation and application.

\section{Avascular necrosis}

The use of BMAC in avascular necrosis (AVN) [19, 21, 33-38], particularly of the femoral head [19, 36, 37, 39-42] has been described by a number of authors. In 2002, Hernigou and Beaujean [19] were the first to describe a protocol for BMAC injection combined with conventional core decompression (CD) to manage AVN of the femoral head. They studied 189 hips in which BMAC obtained from the iliac crest was inserted into the necrotic area within the femoral head. They reported excellent outcomes in hips at the pre-collapse stage, with total hip replacement (THR) only warranted in 9/145 (6.2\%) of the hips studied at five years follow-up.

The same cohort of patients was evaluated in a more recent retrospective analysis [41], 94 of 534 (17\%) hips needed a 
Table 2. Clinical trials of stem cells and orthopaedic applications registered at ClinicalTrials.gov (June 2015).

\begin{tabular}{|c|c|c|c|c|c|c|c|}
\hline Phase & Cell type & Status & Condition & $\begin{array}{l}\text { Number } \\
\text { enrolled }\end{array}$ & Institute & Completion & Access No. \\
\hline & Stem cells & Enrolling & Hip arthroplasty & 50 & $\begin{array}{c}\text { University of } \\
\text { Nebraska }\end{array}$ & April 2012 & NCT01366911 \\
\hline II & MSCs & Recruiting & $\begin{array}{l}\text { Knee cartilage } \\
\text { injuries }\end{array}$ & 16 & $\begin{array}{l}\text { University of } \\
\text { Jordan }\end{array}$ & June 2015 & NCT02118519 \\
\hline II/III & $\begin{array}{l}\text { Autologous } \\
\text { MSCs }\end{array}$ & Unknown & $\begin{array}{l}\text { Articular cartilage } \\
\text { defects }\end{array}$ & 25 & Cairo University & December 2014 & NCT00891501 \\
\hline II & $\begin{array}{l}\text { Autologous } \\
\text { MSCs }\end{array}$ & Not recruiting & $\begin{array}{l}\text { Achilles } \\
\text { tendinopathy }\end{array}$ & 10 & $\begin{array}{l}\text { University College } \\
\text { London }\end{array}$ & May 2016 & NCT02064062 \\
\hline II & $\begin{array}{l}\text { Allogeneic } \\
\text { MSCs }\end{array}$ & Unknown & Osteoarthritis & 60 & $\begin{array}{l}\text { Stempeutics } \\
\text { Research } \\
\text { Pvt Ltd }\end{array}$ & July 2014 & NCT01453738 \\
\hline 0 & $\begin{array}{l}\text { Allogeneic } \\
\text { UCMSCs }\end{array}$ & Enrolling & $\begin{array}{l}\text { Osteochondral } \\
\text { lesion of talus }\end{array}$ & 28 & $\begin{array}{l}\text { Samsung Medical } \\
\text { Centre }\end{array}$ & August 2015 & NCT02338375 \\
\hline $\mathrm{I} / \mathrm{II}$ & MSCs & Completed & Meniscectomy & 55 & Mesoblast & April 2008 & NCT00225095 \\
\hline I & MSCs & Unknown & Bone healing & 5 & $\begin{array}{c}\text { University of } \\
\text { Indonesia }\end{array}$ & December 2014 & NCT01725698 \\
\hline II & MSCs & Recruiting & $\begin{array}{l}\text { Hip avascular } \\
\text { necrosis }\end{array}$ & 30 & $\begin{array}{l}\text { Universidad } \\
\text { Autónoma de } \\
\text { Madrid }\end{array}$ & February 2017 & NCT02065167 \\
\hline $\mathrm{I} / \mathrm{II}$ & $\begin{array}{l}\text { Autologous } \\
\text { MSCs }\end{array}$ & Unknown & $\begin{array}{l}\text { Chondral knee } \\
\text { defects }\end{array}$ & 30 & $\begin{array}{l}\text { Fundación para } \\
\text { la Investigación } \\
\text { Biomédica del } \\
\text { Hospital } \\
\text { Universitario } \\
\text { La Paz }\end{array}$ & June 2012 & NCT01399749 \\
\hline II & $\begin{array}{l}\text { Allogeneic } \\
\text { MSCs }\end{array}$ & Recruiting & $\begin{array}{c}\text { Tibial closed } \\
\text { diaphyseal } \\
\text { fractures }\end{array}$ & 40 & Royan Institute & December 2015 & NCT02140528 \\
\hline \multirow[t]{3}{*}{ I/II } & MSCs & $\begin{array}{l}\text { Active, } \\
\text { not } \\
\text { recruiting }\end{array}$ & Knee osteoarthritis & 30 & $\begin{array}{l}\text { University of } \\
\text { Navarra }\end{array}$ & November 2014 & NCT02123368 \\
\hline & & Enrolling & $\begin{array}{l}\text { Posterolateral } \\
\text { lumbar fusion }\end{array}$ & 60 & University of Utah & January 2016 & NCT01409954 \\
\hline & $\begin{array}{l}\text { Autologous } \\
\text { MSCs }\end{array}$ & Completed & $\begin{array}{l}\text { Fracture non-union } \\
\text { healing }\end{array}$ & 35 & Keele University & October 2011 & NCT02177565 \\
\hline I/II & MSCs/PRP & Recruiting & OA knee & 24 & Aditya K Aggarwal & June 2014 & NCT01985633 \\
\hline I & $\begin{array}{l}\text { Autologous } \\
\text { MScs }\end{array}$ & Completed & $\begin{array}{l}\text { Ankle joint } \\
\text { osteoarthritis }\end{array}$ & 6 & Royan Institute & $\begin{array}{l}\text { September } \\
2011\end{array}$ & NCT01436058 \\
\hline III & BMMSCs & Recruiting & $\begin{array}{l}\text { Talar osteochondral } \\
\text { lesion }\end{array}$ & 140 & $\begin{array}{l}\text { Istituto Ortopedico } \\
\text { Rizzoli }\end{array}$ & June 2015 & NCT02005861 \\
\hline I & BMMSCs & Completed & Bone cyst & 6 & Royan Institute & October 2011 & NCT01207193 \\
\hline \multirow[t]{2}{*}{ II/III } & MSCs & Withdrawn & $\begin{array}{l}\text { Benign bone } \\
\text { lesion }\end{array}$ & 0 & Emory University & March 2010 & NCT00851162 \\
\hline & $\begin{array}{l}\text { Allogeneic } \\
\text { MSCs }\end{array}$ & $\begin{array}{l}\text { Active, } \\
\text { not } \\
\text { recruiting }\end{array}$ & $\begin{array}{l}\text { Subtalar } \\
\text { arthrodesis }\end{array}$ & 140 & AlloSource & February 2017 & NCT01413061 \\
\hline I/II & $\begin{array}{l}\text { Autologous } \\
\text { MSCs }\end{array}$ & $\begin{array}{l}\text { Active, } \\
\text { not } \\
\text { recruiting }\end{array}$ & $\begin{array}{l}\text { Enhance bone } \\
\text { healing }\end{array}$ & 30 & $\begin{array}{l}\text { Institut National } \\
\text { de la Santé et } \\
\text { de la Recherche } \\
\text { Médicale, France }\end{array}$ & November 2015 & NCT01842477 \\
\hline III & $\begin{array}{l}\text { Autologous } \\
\text { osteoblasts }\end{array}$ & Recruiting & Osteonecrosis & 130 & $\begin{array}{l}\text { Bone Therapeutics } \\
\text { S.A. }\end{array}$ & June 2017 & NCT01529008 \\
\hline \multirow[t]{2}{*}{ II/III } & $\begin{array}{l}\text { Autologous } \\
\text { MSCs }\end{array}$ & Recruiting & $\begin{array}{l}\text { Non-union } \\
\text { treatments }\end{array}$ & 60 & Royan Institute & August 2017 & NCT02448849 \\
\hline & MSCs & Unknown & Osteoarthritis & 30 & $\begin{array}{l}\text { University of } \\
\text { Dresden }\end{array}$ & December 2010 & NCT01038596 \\
\hline
\end{tabular}


Table 2. (continued)

\begin{tabular}{|c|c|c|c|c|c|c|c|}
\hline Phase & Cell type & Status & Condition & $\begin{array}{l}\text { Number } \\
\text { enrolled }\end{array}$ & Institute & Completion & Access No. \\
\hline$\overline{\text { II }}$ & MPCs & $\begin{array}{l}\text { Active, } \\
\text { not recruiting }\end{array}$ & $\begin{array}{l}\text { Lumbar back } \\
\text { pain }\end{array}$ & 100 & Mesoblast & July 2015 & NCT01290367 \\
\hline $\mathrm{I} / \mathrm{II}$ & $\begin{array}{l}\text { Autologous } \\
\text { MSCs }\end{array}$ & Recruiting & Knee OA & 12 & $\begin{array}{c}\text { University of } \\
\text { Toronto }\end{array}$ & February 2021 & NCT02351011 \\
\hline III & $\begin{array}{l}\text { Allogeneic } \\
\text { MSCs }\end{array}$ & Recruiting & $\begin{array}{l}\text { Chondrogenic } \\
\text { discogenic } \\
\text { lumbar back pain }\end{array}$ & 330 & Mesoblast & $\begin{array}{l}\text { December } \\
2017\end{array}$ & NCT02412735 \\
\hline II & MSCs & Active, not recruiting & $\begin{array}{l}\text { Lumbar interbody } \\
\text { fusion }\end{array}$ & 24 & Mesoblast & July 2015 & NCT00996073 \\
\hline
\end{tabular}

THR at a mean follow-up of 13 years. Of these, 69 hips (18\%) demonstrated complete resolution of the necrotic area on magnetic resonance imaging (MRI). These findings are similar to those reported by Martin et al. who used BMAC and PRP following minimally invasive $\mathrm{CD}$ of the femoral head (FH) for AVN in 77 hips [43].

Hendrich et al. [44] used autologous BMAC in the management of AVN in 37 femoral heads and 32 areas of AVN in other locations. The study also included 12 non-unions and 20 other bone defects. The injection of BMAC was performed as part of a CD. They reported that $84 / 101(83 \%)$ of patients were highly satisfied, 7/101(6.9\%) moderately satisfied and $1 / 101(1 \%)$ expressed poor satisfaction after a mean follow-up period of 14 months (2-24 months). In their opinion, the preparation of the BMAC within the operating theatre was a viable one-step autologous cell therapy for bone regeneration [44].

In a prospective randomised controlled trial undertaken by Sen et al. [45], 51 hips with AVN in 40 patients were randomly divided into two treatment groups. Twenty-six hips were managed with $\mathrm{CD}$ and 26 hips were treated with BMAC injection. The Harris Hip Score and mean hip survival were significantly better in the BMAC group $(p<0.05)$. In the largest study carried out by Zhao et al., 100 patients were recruited. Fifty-one hips underwent $\mathrm{CD}$ while 53 hips were managed by BMAC injection. In the $\mathrm{CD}$ group, $10 / 51(20 \%)$ of hips compared to $2 / 53(3.7 \%)$ of hips in the BMAC group collapsed and finally required a second surgery [45].

In summary, BMAC injection yields satisfactory outcomes in AVN of the femoral head, early diagnosis and treatment prior to bone collapse are linked with better results.

\section{Cartilage defects}

The repair of cartilage defects in animal models is well established. This has been extended to human studies with Gobbi et al. [46] using a single-step technique with BMAC placed on a collagen matrix in 15 patients treated for grade 4 cartilage defects in the knee at 24 months follow-up. Patients showed significant improvement in Visual Analogue Scale (VAS), International Knee Documentation Committee score (IKDC) and Knee injury and Osteoarthritis Outcome Score (KOOS) at final follow-up $(p<0.005)$. Superior outcomes were reported in patients with solitary cartilage defects and those with small lesions. MRI and histology confirmed hyaline-like tissue coverage of the lesions.

The use of BMAC as a single-step technique for the reconstruction of cartilage defects of the talus has been compared to open or arthroscopic autologous chondrocyte implantation (ACI) by Giannini et al. [47]. Eighty-one patients with an average age of $30 \pm 8$ years were reported. In both treatment groups, a hyaluronic acid membrane was used. A second look arthroscopy was undertaken in all patients with a biopsy at 12 months postsurgery. For all groups the mean American Orthopaedic Foot and Ankle Society (AOFAS) score improved significantly $(p<0.0005)$ at an average of $59.5 \pm 26.5$ months. There were no significant differences in the change of AOFAS scores between the three groups. Histological evaluations emphasised the formation of type II collagen and proteoglycan expression. However, BMAC provided the advantage of permitting a noticeable decrease in morbidity as a "one-step" technique.

A nonrandomised prospective comparative trial by Gobbi et al. [48] compared the outcome of matrix-induced autologous chondrocyte implantation (MACI) versus BMAC implantation, using the same hyaluronic scaffold, in the patellofemoral joint at a minimum of three years postsurgery. They reported no adverse or postoperative surgical complications in either group. The two groups demonstrated significant improvement in the IKDC, KOOS as well as the VAS, and Tegner score $(p=0.001)$, the IKDC score in the BMAC group demonstrated significantly superior compared to MACI $(p=0.015)$. Trochlear lesions displayed superior outcomes when compared with the patellar lesions in the MACI group. This observation was not found in the BMAC group, as the location was not a prognostic factor. Complete filling of the defect on MRI was $76 \%$ in the MACI group compared to $81 \%$ in the BMAC group [48].

There is a clear need for future research to review the long-term outcomes of autologous chondrocyte transplantation versus bone marrow derived MSC in the form of BMAC. Short-term outcomes look very promising and may enhance established techniques.

\section{Tendon injury}

Tendon injuries are common musculoskeletal presentations and the potential regeneration and repair properties of 
BMAC have been explored with promising results. A case series reported by Ellera Gomes et al. [49] reviewed 14 patients (nine women, five men) with full thickness rotator cuff tears managed with transosseous sutures augmented with BMAC utilising a mini-open technique. All patients were followed up for a minimum of one year. They reported significant improvement in the University of California, Los Angeles (UCLA) score improving from $12 \pm 3.0$ to $31 \pm 3.2$ at 12 months postsurgery. There were no re-tears reported, however six patients (42\%) had high-signal intensity at the critical zone. One revision was reported at two years follow-up.

Hernigou et al. [50] evaluated the efficiency of BMAC compared to that of a matched control group in augmenting arthroscopic single row rotator cuff repair. Patients treated with BMAC demonstrated superior outcomes with improved healing rates and enhanced quality of the repaired tendon, as demonstrated by ultrasound and MRI. Forty-five shoulders $(100 \%)$ of the BMAC group demonstrated tendon healing by six months, compared to only 30 shoulders $(67 \%)$ in the control group at the same time point. Furthermore, at tenyear follow-up, the integrity of the repair was maintained in $39(87 \%)$ shoulders in the BMAC group compared to only $20(44 \%)$ in the control group.

A prospective multicentre study by Centeno et al. [51] compared the use of BMAC for the treatment of osteoarthritis (OA) with and without rotator cuff pathology. A total of 115 shoulders were treated with BMAC injection principally for glenohumeral OA with or without a rotator cuff tear. The mean disabilities of the arm, shoulder and hand score [52] and VAS improved significantly from 36.1 to $17.1(p<0.001)$ and 4.3 to $2.4(p<0.001)$, respectively. These results were consistent with a mean subjective improvement of $48.8 \%$. They reported no significant adverse events at two years follow-up postsurgery.

The use of BMAC in rotator cuff repair has shown initial success in small studies. There is a need for larger scale studies to fully define the potential role of BMAC's role as an augment and how best to deliver it at the repair site.

\section{Conclusions}

Mesenchymal Stem Cells in BMAC have the potential to self-renew, undertake clonal expansion, and differentiate into different musculoskeletal tissues. MSCs are also known to have an immunoregulatory role and may enhance the normal healing response. BMAC has been used in bone, cartilage and tendon injuries with encouraging results. Alongside well-designed clinical trials, further basic science work is required to investigate the therapeutic action of BMAC. The commercial processing of BMAC needs to be optimised in order to achieve a consistent end product, which will provide predicable and translatable results. The future potential of cell characterisation in order to determine the optimum cell for repair/regeneration of various tissue types also needs to be explored.

\section{Conflict of interest}

The authors declare no conflict of interest in relation with this paper.

Acknowledgements. Authors certify that their institution has approved the conduction of and their participation in this study, and that the study has been performed in accordance with the ethical standards laid down in the 1964 Declaration of Helsinki and its later amendments.

\section{References}

1. Baksh D, Song L, Tuan RS (2004) Adult mesenchymal stem cells: characterization, differentiation, and application in cell and gene therapy. J Cell Mol Med 8(3), 301-316.

2. Gulotta LV, Kovacevic D, Ehteshami JR, Dagher E, Packer JD, Rodeo SA (2009) Application of bone marrow-derived mesenchymal stem cells in a rotator cuff repair model. Am J Sports Med 37(11), 2126-2133.

3. Nejadnik H, Hui JH, Feng Choong EP, Tai BC, Lee EH (2010) Autologous bone marrow-derived mesenchymal stem cells versus autologous chondrocyte implantation: an observational cohort study. Am J Sports Med 38(6), 1110-1116.

4. Brazelton TR, Rossi FM, Keshet GI, Blau HM (2000) From marrow to brain: expression of neuronal phenotypes in adult mice. Science 290(5497), 1775-1779.

5. Bruder SP, Jaiswal N, Haynesworth SE (1997) Growth kinetics, self-renewal, and the osteogenic potential of purified human mesenchymal stem cells during extensive subcultivation and following cryopreservation. J Cell Biochem 64(2), 278-294.

6. Kopen GC, Prockop DJ, Phinney DG (1999) Marrow stromal cells migrate throughout forebrain and cerebellum, and they differentiate into astrocytes after injection into neonatal mouse brains. Proc Natl Acad Sci USA 96(19), 10711-10716.

7. Xie A, Nie L, Shen G, Cui Z, Xu P, Ge H, Tan Q (2014) The application of autologous plateletrich plasma gel in cartilage regeneration. Mol Med Rep 10(3), 1642-1648.

8. Majumdar MK, Thiede MA, Mosca JD, Moorman M, Gerson SL (1998) Phenotypic and functional comparison of cultures of marrow-derived mesenchymal stem cells (MSCs) and stromal cells. J Cell Physio 176(1), 57-66.

9. Bain BJ (1996) The bone marrow aspirate of healthy subjects. Br J Haematol 94(1), 206-209.

10. Yamamura R, Yamane T, Hino M, Ohta K, Shibata H, Tsuda I, Tatsumi N (2002) Possible automatic cell classification of bone marrow aspirate using the CELL-DYN 4000 automatic blood cell analyzer. J Clin Lab Anal 16(2), 86-90.

11. Kim M, Kim J, Lim J, Kim Y, Han K, Kang CS (2004) Use of an automated hematology analyzer and flow cytometry to assess bone marrow cellularity and differential cell count. Ann Clin Lab Sci 34(3), 307-313.

12. Fortier LA, Potter HG, Rickey EJ, Schnabel LV, Foo LF, Chong LR, Stokol T, Cheetham J, Nixon AJ (2010) Concentrated bone marrow aspirate improves full-thickness cartilage repair compared with microfracture in the equine model. J Bone Joint Surg Am 92(10), 1927-1937. 
13. Hyer CF, Berlet GC, Bussewitz BW, Hankins T, Ziegler HL, Philbin TM (2013) Quantitative assessment of the yield of osteoblastic connective tissue progenitors in bone marrow aspirate from the iliac crest, tibia, and calcaneus. J Bone Joint Surg Am 95(14), 1312-1316.

14. Batinic D, Marusic M, Pavletic Z, Bogdanic V, Uzarevic B, Nemet D, Labar B (1990) Relationship between differing volumes of bone marrow aspirates and their cellular composition. Bone Marrow Transplant 6(2), 103-107.

15. Muschler GF, Boehm C, Easley K (1997) Aspiration to obtain osteoblast progenitor cells from human bone marrow: the influence of aspiration volume. J Bone Joint Surg Am 79(11), 1699-1709.

16. Hernigou J, Picard L, Alves A, Silvera J, Homma Y, Hernigou P (2014) Understanding bone safety zones during bone marrow aspiration from the iliac crest: the sector rule. Int Orthop 38(11), 2377-2384.

17. Hernigou P, Homma Y, Flouzat Lachaniette $\mathrm{CH}$, Poignard A, Allain J, Chevallier N, Rouard H (2013) Benefits of small volume and small syringe for bone marrow aspirations of mesenchymal stem cells. Int Orthop 37(11), 2279-2287.

18. Health Quality Ontario (2005) Osteogenic protein-1 for long bone nonunion: an evidence-based analysis. Ontario Health Technology Assessment Series 5(6), 1-57.

19. Hernigou P, Beaujean F (2002) Treatment of osteonecrosis with autologous bone marrow grafting. Clin Orthop Relat Res 405, 14-23.

20. Pittenger MF, Mackay AM, Beck SC, Jaiswal RK, Douglas R, Mosca JD, Moorman MA, Simonetti DW, Craig S, Marshak DR (1999) Multilineage potential of adult human mesenchymal stem cells. Science 284(5411), 143-147.

21. Hernigou P, Poignard A, Beaujean F, Beaujean F, Rouard H, Rouard H (2005) Percutaneous autologous bone-marrow grafting for nonunions. Influence of the number and concentration of progenitor cells. J Bone Joint Surg Am 87(7), 1430-1437.

22. Lee DH, Ryu KJ, Kim JW, Kang KC, Choi YR (2014) Bone marrow aspirate concentrate and platelet-rich plasma enhanced bone healing in distraction osteogenesis of the tibia. Clin Orthop Relat Res 472(12), 3789-3797.

23. Jager M, Jelinek EM, Wess KM, Scharfstadt A, Jacobson M, Kevy SV, Krauspe R (2009) Bone marrow concentrate: a novel strategy for bone defect treatment. Current Stem Cell Research \& Therapy 4(1), 34-43.

24. Muschler GF, Nitto H, Matsukura Y, Boehm C, Valdevit A, Kambic H, Davros W, Powell K, Easley K (2003). Spine fusion using cell matrix composites enriched in bone marrow-derived cells. Clin Orthop Relat Res 407, 102-118.

25. McCarrel T, Fortier L (2009). Temporal growth factor release from platelet-rich plasma, trehalose lyophilized platelets, and bone marrow aspirate and their effect on tendon and ligament gene expression. J Orthop Res 27(8), 1033-1042.

26. Moher D., Moher D., Liberati A., Tetzlaff J., Tetzlaff J., Altman D.G., Altman D.G., Group P., Group P. (2009) Preferred reporting items for systematic reviews and meta-analyses: the PRISMA statement. J Clin Epidemiol 62(10), 1006-1012.

27. Hyde M, Higgs P, Wiggins RD, Blane D (2015) A decade of research using the CASP scale: key findings and future directions. Aging Ment Health 19(7), 571-575.

28. Hernigou P, Mathieu G, Poignard A, Manicom O, Manicom O, Beaujean F, Beaujean F, Rouard H (2006) Percutaneous autologous bone-marrow grafting for nonunions. Surgical technique. J Bone Joint Surg Am 88, 322-327.
29. Kasten P, Beyen I, Egermann M, Suda AJ, Moghaddam AA, Zimmermann G, Luginbuhl R (2008) Instant stem cell therapy: characterization and concentration of human mesenchymal stem cells in vitro. Eur Cell Mater 16, 47-55.

30. Connolly J, Guse R, Lippiello L, Dehne R (1989) Development of an osteogenic bone-marrow preparation. J Bone Joint Surg Am 71(5), 684-691.

31. Kassem MS (2013) Percutaneous autogenous bone marrow injection for delayed union or non union of fractures after internal fixation. Acta Orthop Belg 79(6), 711-717.

32. Hernigou P, Guissou I, Homma Y, Poignard A, Chevallier N, Rouard H, Flouzat Lachaniette CH (2015) Percutaneous injection of bone marrow mesenchymal stem cells for ankle non-unions decreases complications in patients with diabetes. Int Orthop 39(8), 1639-1643.

33. Yoshioka T, Mishima H, Akaogi H, Sakai S, Li M, Ochiai N (2011) Concentrated autologous bone marrow aspirate transplantation treatment for corticosteroid-induced osteonecrosis of the femoral head in systemic lupus erythematosus. Int Orthop 35(6), 823-829.

34. Zhao D, Liu B, Wang B, Yang L, Xie H, Huang S, Zhang Y, Wei X. (2015) Autologous bone marrow mesenchymal stem cells associated with tantalum rod implantation and vascularized iliac grafting for the treatment of end-stage osteonecrosis of the femoral head. BioMed Research International 2015, 240506.

35. Zhao D, Cui D, Wang B, Tian F, Guo L, Yang L, Liu B, Yu X (2012) Treatment of early stage osteonecrosis of the femoral head with autologous implantation of bone marrow-derived and cultured mesenchymal stem cells. Bone 50(1), 325-330.

36. Gangji V, Gangji V, Hauzeur JP, Hauzeur JP, Hauzeur JP, Matos C, Matos C, De Maertelaer V, Toungouz M, Lambermont M (2004) Treatment of osteonecrosis of the femoral head with implantation of autologous bone-marrow cells. A pilot study. J Bone Joint Surg Am 86-A(6), 1153-1160.

37. Gangji V, Hauzeur JP (2005) Treatment of osteonecrosis of the femoral head with implantation of autologous bonemarrow cells. Surgical technique. J Bone Joint Surg Am 87, Suppl 1 (Pt 1), 106-112.

38. Yasunaga $\mathrm{Y}$, Terayama $\mathrm{H}$, Yamasaki $\mathrm{T}$, Ishikawa M, Ochi M (2007) Treatment of osteonecrosis of the femoral head with implantation of autologous bone-marrow mononuclear cells. Clin Calcium 17(6), 910-915.

39. Kawate K, Yajima H, Ohgushi H, Kotobuki N, Sugimoto K, Ohmura T, Kobata Y, Shigematsu K, Kawamura K, Tamai K, Takakura Y (2006) Tissue-engineered approach for the treatment of steroid-induced osteonecrosis of the femoral head: transplantation of autologous mesenchymal stem cells cultured with beta-tricalcium phosphate ceramics and free vascularized fibula. J Artif Organs 30(12), 960-962.

40. Noth U, Reichert J, Reppenhagen S, Steinert A, Rackwitz L, Eulert J, Beckmann J, Tingart M (2007) Cell based therapy for the treatment of femoral head necrosis. Der Orthopade 36(5), 466-471.

41. Hernigou P, Poignard A, Zilber S, Rouard H (2009) Cell therapy of hip osteonecrosis with autologous bone marrow grafting. Indian J Orthop 43(1), 40-45.

42. Gangji V, De Maertelaer V, Hauzeur JP (2011) Autologous bone marrow cell implantation in the treatment of nontraumatic osteonecrosis of the femoral head: Five year follow-up of a prospective controlled study. Bone 49(5), 1005-1009. 
43. Martin JR, Houdek MT, Sierra RJ (2013) Use of concentrated bone marrow aspirate and platelet rich plasma during minimally invasive decompression of the femoral head in the treatment of osteonecrosis. Croat Med J 54(3), 219-224.

44. Hendrich C, Franz E, Waertel G, Krebs R, Jager M (2009) Safety of autologous bone marrow aspiration concentrate transplantation: initial experiences in 101 patients. Orthop Rev 1(2), e32.

45. Sen RK, Tripathy SK, Aggarwal S, Marwaha N, Sharma RR, Khandelwal N (2012) Early results of core decompression and autologous bone marrow mononuclear cells instillation in femoral head osteonecrosis: a randomized control study. J Arthroplasty 27(5), 679-686.

46. Gobbi A, Karnatzikos G, Scotti C, Mahajan V, Mazzucco L, Grigolo B (2011) One-step cartilage repair with bone marrow aspirate concentrated cells and collagen matrix in full-thickness knee cartilage lesions: results at 2-year follow-up. Cartilage 2(3), 286-299.

47. Giannini S, Buda R, Cavallo M, Ruffilli A, Cenacchi A, Cavallo C, Vannini F (2010) Cartilage repair evolution in posttraumatic osteochondral lesions of the talus: from open field autologous chondrocyte to bone-marrow-derived cells transplantation. Injury 41(11), 1196-1203.
48. Gobbi A, Chaurasia S, Karnatzikos G, Nakamura N (2015). Matrix-induced autologous chondrocyte implantation versus multipotent stem cells for the treatment of large patellofemoral chondral lesions: a nonrandomized prospective trial. Cartilage 6(2), 82-97.

49. Ellera Gomes JL, da Silva RC, Silla LM, Abreu MR, Pellanda $R$ (2012) Conventional rotator cuff repair complemented by the aid of mononuclear autologous stem cells. Knee Surg Sports Traumatol Arthrosc 20(2), 373-377.

50. Hernigou P, Flouzat Lachaniette $\mathrm{CH}$, Delambre J, Zilber S, Duffiet P, Chevallier N, Rouard H (2014) Biologic augmentation of rotator cuff repair with mesenchymal stem cells during arthroscopy improves healing and prevents further tears: a casecontrolled study. Int Orthop 38(9), 1811-1818.

51. Centeno CJ, Al-Sayegh H, Bashir J, Goodyear S, Freeman MD (2015) A prospective multi-site registry study of a specific protocol of autologous bone marrow concentrate for the treatment of shoulder rotator cuff tears and osteoarthritis. J Pain Res 8, 269-276.

52. Dashottar A, Costantini O, Borstad J (2014) A comparison of range of motion change across four posterior shoulder tightness measurements after external rotator fatigue. Int J Sports Phys Ther 9(4), 498-508.

Cite this article as: Imam MA, Mahmoud SSS, Holton J, Abouelmaati D, Elsherbini Y \& Snow M (2017) A systematic review of the concept and clinical applications of Bone Marrow Aspirate Concentrate in Orthopaedics. SICOT J, 3, 17 